\title{
Trust Revenue of Commercial Banks: The Influence of Bank Holding Companies
}

\author{
R. ALTON GILBERT
}

I

N ADMINISTERING the Bank Holding Company Act, the Federal Reserve Board weighs the public benefits from proposed acquisitions by bank holding companies (hereafter called BHCs) against possible adverse competitive effects. ${ }^{1} \mathrm{BHCs}$ are asked to discuss public benefits of proposed acquisitions in applications to acquire banks and nonbanking firms. A public benefit commonly mentioned in applications for the acquisition of additional banks is increased trust services to be offered to customers in the areas of the proposed subsidiaries. ${ }^{2}$

Banks outside metropolitan areas and banks with relatively few customers generally do not have enough potential trust customers to justify hiring a staff to specialize in trust services. In some applications BHCs indicate plans for sharing the expertise of trust department employees of their larger banks with the proposed subsidiaries. In other cases the BHCs plan to offer trust services directly through the trust departments of their larger banks. It is contended that under both policies the potential customers of the banks to be acquired would have opportunities of receiving better trust services as a result of the affiliation of local banks with BHCs.

\footnotetext{
1Section 3(c) (2) of the Bank Holding Company Act of 1956 as amended reads as follows: The Board shall not approve any other proposed acguisition or merger or consolidation ander this section whose effect in any section of the country may be substantially to lessen competition, or to tend to create a monopoly, or which in any other manner would be in restraint of trade, mless it finds that the anticompetitive effects of the proposed transactions are clearly outweighed in the public interest by the probable effect of the transaction in meeting the convenience and needs of the community to be served.

${ }^{2}$ See orders on bank holding company cases published in the Federal heserve Bulletin.
}

The objective of this paper is to determine whether the amount of trust business in areas served by banks affiliated with BHCs is significantly different from that in areas not served by affiliated banks. Several variables, in addition to the affiliation of banks with $\mathrm{BHCs}$, are included in regression analyses to estimate the influence of BHCs on the trust business of banks in areas served by their subsidiaries.

The paper is divided into three sections. The first section discusses the measure of trust business and the variables used to explain the level of trust business. The second describes the sample of banks used to estimate the influences of these variables on the trust business of banks. The third section presents empirical tests of hypotheses.

\section{DETERMINANTS OR THE LFEL OT TTUST BUSTNGSS WN MOTVTOUA APEAS}

The model specifies the factors which are presumed to influence the demand for trust services by individual bank customers and the supply of trust services by individual banks. The theoretical demand and supply functions are aggregated across individuals, firms, and banks, and a reduced form equation is specified which indicates how the demand and supply factors influence the level of trust services. The measure of trust business in an area is the revenue of bank trust departments per capita; trust revenue equals the quantity of trust services multiplied by the price of trust services. Measurement of the influences on the demand for and supply of trust services is discussed in the section where these influences are combined in a reduced form equation. Some influences on the trust 
business of banks are mentioned, but not measured, due to a lack of data.

\section{Demand for The Services}

Individuals demand trust services to secure management of their wealth. Some trust arrangements are established by wills which give trust departments authority to sell the assets of estates and distribute the proceeds to the beneficiaries. Other trust accounts are established as living trusts under which individuals, while still alive, transfer legal title to part of their wealth to trust departments to be invested and disposed of as the trust agreements specify. Under another type of arrangement, a trust department does not own the assets of an individual, but acts as an agent in managing his portfolio or giving investment advice. ${ }^{3}$

The demand for trust services by an individual is assumed to be positively related to his wealth and, holding wealth constant, positively related to his age. Holding constant the influence of wealth, an individual is more likely to establish a living trust as he gets older and considers the problems associated with transferring an estate to his family. Also, influences like poor health may induce older people to use trust departments as agents for investing their wealth. The demand for trust services by an individual at banks in the area in which he lives is assumed to be negatively related to the price of trust services in that area; positively related to the prices of trust services in nearby cities and to the prices of alternatives to trust services; and positively related to the length of time the individual has been in the area. If this individual has moved into the area recently, he is more likely to have established a trust account at a bank outside of the area than someone who has lived in the area all of his life. The prices of trust services in nearby cities and the prices of alternatives to trust services are not measured in this paper and therefore are not mentioned again as determinants of trust services.

Business firms demand trust services mainly for the management of funds in employee benefit programs. This source of demand at banks in an area is assumed to be positively related to the percentage of employees in the area that are accumulating pension benefits. Although trust departments provide other services for

${ }^{3}$ For more details on the operations of bank trust departments see Edna E. Ehrlich, "The Functions and Investment Policies of Personal Trust Departments, I and II," Federal Reserve Bank of New York Monthly Review (Oct. 1972 and Jantary 1973). business firms, no variables are included in the analysis to explain the demand for those services.

The total demand for trust services at banks in a particular area is assumed to be a function of the following variables:

(a) the total wealth of people in the area and surrounding areas $(+)$;

(b) the percentage of individuals in the area and surrounding areas that have enough wealth to make management of their wealth by trust departments profitable for trust departments and an efficient means for individuals to invest their wealth $(+)$. Some of the costs to a bank of establishing a trust account do not depend upon the size of the estate to be managed. Such costs include those of talking to the customer about the purpose of the trust and distributing the profits from the investments. At the prices trust departments would have to charge to just cover the cost of managing small estates, other ways of investing would be more efficient for those individuals with relatively small amounts of wealth. Therefore, the effective demand for trust services is assumed to depend upon the allocation of wealth. These two variables, (a) and (b), are independent if the degree of inequality in the distribution of wealth varies sufficiently among individual areas.

(c) the average age of people in the area $\left(+_{+}\right)$;

(d) the price of trust services in the area (-);

(e) recent migration into the area (-), a measure inversely related to the length of time individuals have lived in the area.

(f) the degree to which people in stirrounding areas come into the area for reasons other than just shopping for trust services $(+)$. Some of the potential trust customers of banks in a particular county live in surrounding counties. There are costs to these potential customers of coming to establish trust accounts in terms of travel time and explicit travel costs. These costs are smaller for people from surrounding counties who regularly come into the county for reasons other than shopping for trust services, such as commuting to work, entertainment, and general shopping.

(g) the influence of BHCs (-). Some BHCs instruct their smaller bank subsidiaries to refer 
trust customers to the trust departments of the large bank subsidiaries of the BHCs. If this is the general policy of BHCs, the amount of trust services demanded by local customers at local banks would tend to be lower at each price charged by local banks for trust services.

(h) the percentage of employees in the area that are accumulating pension benefits $(+)$.

\section{Supply of Trust Services}

Some of the functions performed in managing trust assets are the same as those involved in other operations of a bank, such as buying and selling govemment securities and evaluating the future profit prospects of companies. If the other departments of a bank have enough business to take advantage of some of the economies of scale in banking, the trust department of that bank would have a lower cost structure than the trust department of a smaller bank.

Any influence that lowers the costs to a bank of supplying trust services shifts its supply schedule for trust services so that more trust services are offered at each price. The supply of trust services by an individual bank is assumed to be a function of the following variables: the price of trust services $(+1)$; the costs of inputs, such as labor (-); the volume of transactions at the bank outside of the trust department ( + ); and affiliation of the bank with a BHC $(+)$. The sign of this last variable is positive if BHCs help their subsidiary banks develop their own trust departments. Several studies indicate that there are economies of scale in bank trust departments. Suppose that a BHC helps its subsidiary banks lower their operating costs by pooling operations. This influence on the cost structure of a subsidiary bank would induce it to offer more trust services at each price than it would have without affiating with the BHC. The costs of bank inputs are not measured and therefore are excluded from additional analysis.

"Gerald C. Fischer, Bank Holding Companies (New York: Columbia University Press, 1961), p. 130; Steven Weiss, "Bank Holding Companies and Public Policy," New England Economic Review (January/February 1969), p. 19.

5Frederick W. Bell and Neil B. Muphy, Costs in Commercial Banking, Federal Reserve Bank of Boston Report No. 41 (April 1968), p. 164; Marvin S. Margolis, "Trust Departments - A Suggested Approach for Determining Functional Profitability," Federal Reserve Bank of Dallas Business Review (April 1974), pp. I-5; Neil B, Murphy, "CrossSectional Analysis of the Cost of Operations of Trust Departments," Joumal of Money, Credit and Banking (February 1969), pp. 84-100, Keith $V$. Smith and Maurice B. Goudzwaard, "The Profitability of Commercial Bank Trust Management," Joumal of Bank Research (Autumn 1972), pp. $166-77$.

Page 10
The total supply of trust services by banks in a given area is a function of the following variables:

(a) the price of trust services in the area $(+)$,

(b) the size of the largest bank in the area (+),

(c) the size distribution of banks in the area. Holding constant the size of the largest bank, the quantity of trust services supplied by banks in an area at each price is assumed to be greater the more equal the size distribution of banks in this area. The influence of the size of all banks in the area on the total supply of trust services is captured by items (b) and (c).

(d) the existence of banks in the area that are affiliated with BHCs $(+)$. As explained above, the direction of influence of this variable depends upon the policies of BHCs. The positive sign holds if BHCs help the trust departments of their individual subsidiary banks attract customers.

\section{Reduced form and Empinical Proxies}

As indicated above, the trust business of banks in an area is measured by the revenue of their trust departments per person living in the area. ${ }^{6}$ Demand and supply functions for trust services can be estimated only with separate measures of price and quantity of services. These are not available. However, the revenue of bank trust departments can be specified as a function of variables listed above which influence the supply of and demand for trust services.

Changes in variables that induce an outward shift in the demand function cause trust revente to rise. The influence of shifts in the supply curve depends upon whether the supply curve intersects the demand curve on its elastic or inelastic portion. If the supply curves intersect the elastic portion of the demand curves in all areas under analysis, changes in supply variables that cause the supply curves to shift to the right will increase trust revenue. There is no data to indicate whether this assumption is warranted. Therefore, the direction of influence of supply factors on the trust revenue of banks must be determined empirically; neither positive nor negative signs are hypothesized.

The following list indicates the measurable variaables hypothesized to infuence trust revenue per cap-

BData on trust income is taken from the Report of Income by all commercial banks that are instred by the Federal Deposit Insurance Corporation. 
ita and the directions of influence. A discussion of empirical measurement follows the identification of each variable.

(a) Wealth per capita in the area $(+)$. Data on wealth are not available by county, but measures of income by county are available for population census years. ${ }^{7}$ Trust revenue per capita is hypothesized to be positively related to median family income. A ranking of counties by median family income would approximate the ranking by wealth per capita if no migration takes place, if the share of income saved does not vary among counties, and if the ranking of counties by median family income has remained the same over time.

The last assumption is relaxed by adding the rate of change in median family income as an explanatory variable. If two counties bad the same median income in 1969 , the county with the more rapid growth in median income from 1959 to 1969 would have a lower level of median income in 1959 than the area with slower growth. Accumulated nonhuman wealth would generally be lower in the area with the faster growth in median family income. Therefore, trust reventie per capita is hypothesized to be negatively related to the rate of change in median family income, holding constant the current level of median family income.

(b) The percentage of individuals in the area and surrounding areas that have enough wealth to make management of their wealth by trust departments profitable for trust departments and an efficient means for individuals to invest their wealth $(+)$. This variable is measured as the percentage of families with incomes over $\$ 50,000$ in 1969 . This income level is used because it is a measure of income distribution available from the census reports which is not highly correlated with median family income. Two separate percentages are calculated, one for the county under study and another for the surrounding counties.

(c) The percentage of people in the area old enough to consider trust accounts as a means of managing their assets $(+)$. This variable is

\footnotetext{
TThe term wealth is ised in this paper to refer to nonhuman wealth. For many people the largest portion of their total wealth is their human wealth, that is, the present value of the future earnings they will receive from wotking. Individuals have a use for trust dopartments only when a large portion of their wealth is held in norhuman form.
}

measured as the percentage of population 45 years old or older in the area under study. No alternative measures of age were used.

(d) Migration into the area (-). This variable is measured as the percentage of residents in a county in 1970 who lived in another county in 1965.

(e) The degree to which people in surrounding cotnties come into the county under study for reasons other than shopping for trust services $(+)$. This variable is measured as the population density of the county under study less the population density of surrounding counties. If people shop in an area outside the county in which they live or commute into another area to work, they are likely to go to a county with a higher population density than their home county. ${ }^{8}$

(f) The percentage of workers likely to be accumulating pension benefits $(+)$. A uniform industrial classification of employees is presented by county in the 1970 census. Domestic and farm workers are considered least likely to have pension plans. This variable is measured as the percentage that domestic and farm workers comprise of total employees and is assumed to be negatively related to observed trust services.

(g) The size of the largest bank in the area is measured as total deposits on December 1971 .

(h) The size distrilution of banks in the area. This variable is measured by the Herfindahl Index, computed by squaring the percentage of total deposits held by each bank in the county as of December 1971 and then summing over all banks in the county. The more equally deposits are distributed among banks in a county, the lower this index.

(i) The existence of banks in the area affiliated with BHCs $(+$ or -$)$. This variable is represented by dummy variables, one with a value of unity if one or more banks in a county were affiliated with a BHC on December 1971, zero otherwise, and the other dummy variable with a value of unity if one or more banks in the county were affiliated with BHCs on December 1970 , a value of zero otherwise. The second

\footnotetext{
${ }^{8}$ This hypothesis about shopping behavior is implied from the Central Place Theory. See Hugh O. Nourse, Regional Economics (New York: MeGraw.Hill Book Co., 1968), pp. $33-62$
} 


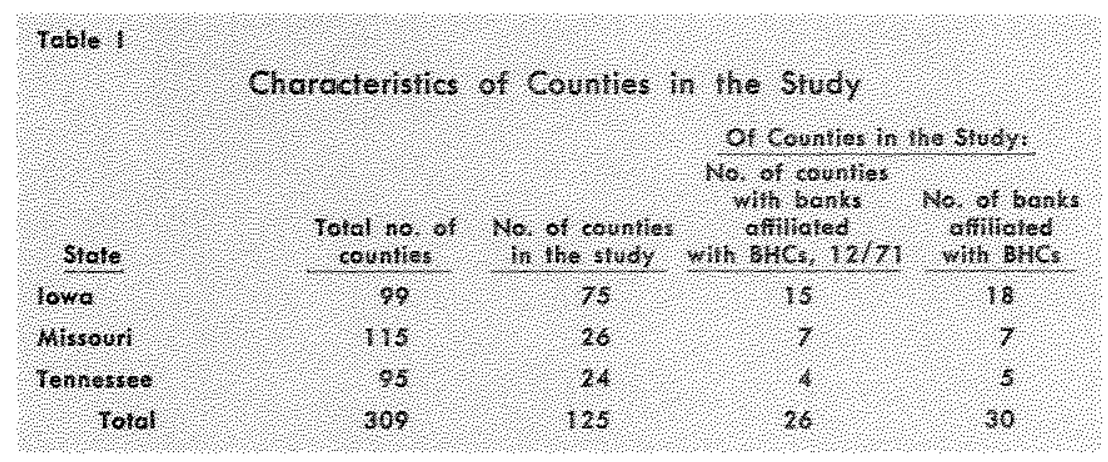

years, and these states appear to have somewhat similar economic characteristics. All nonmerropolitan counties in the three states in which at least one bank reported trust revenue on the $1971 \mathrm{Re}$ port of income are included in the sample ${ }^{10}$ As indicated in Table 1, 26 of the 125 counties had banks affliated with BHCs as of December 1971. Two or more banks were anfliated with BHCs in only three of these comties as of December 1971. Banks were affliated with BuCs in 22 counties as of December 1970.

sibility that the influence of affiliation with BHCs on trust services offered takes at least a year to affect the trust revenue of subsidiary banks. These variables are included separately as independent variables in regression equations.

No hypothesis is made about the direction of influence of these dummy variables on trust revenue per capita. Positive regression coefficients for these variables would indicate that BHCs have helped their smaller subsidiary banks to increase their own trust business. An alternative hypothesis with the same implication is that local banks other than those affiliated with BHCs would improve their trust deparments under the threat that the subsidiary banks would start providing this service if they did not. Negative regression coefficients would provide support for the proposition that BHCs have attracted the potential trust customers of their smaller subsidiary banks to their larger banks. A regression coefficient not significantly different from zero could indicate either that the BHCs have followed different policies in dealing with trust customers or that BHCs have had no

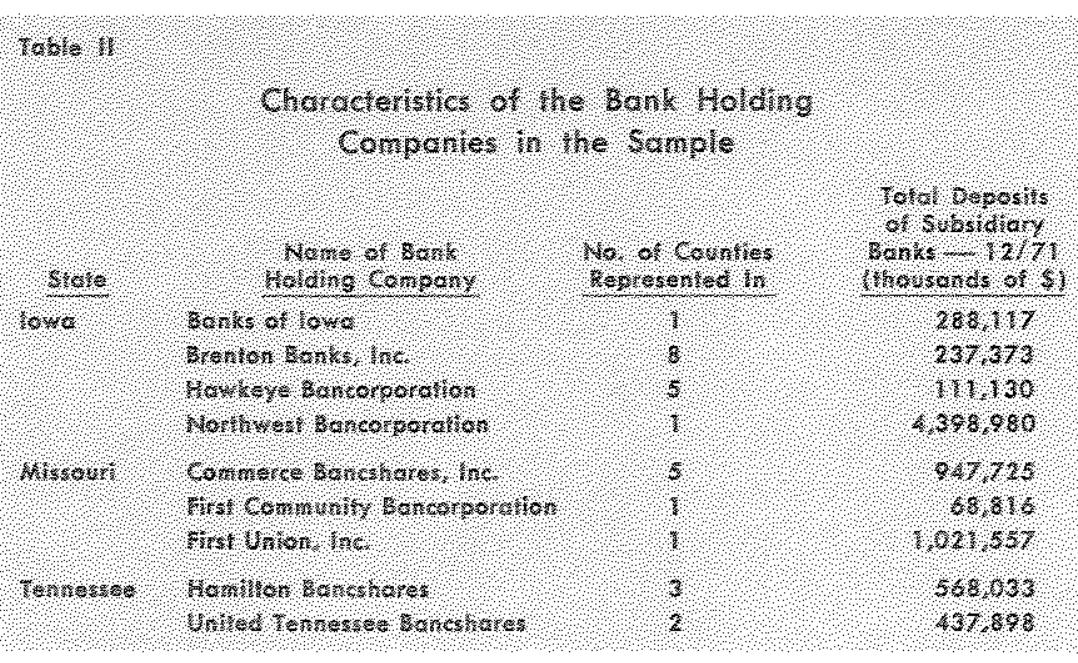
significant infuence on the trust services offered to potential customers of their subsidiary banks.

\section{TWE SAMPLE OP WANKS}

The banks in this study are located in 125 counties in the following states: Iowa (75); Missour (26), and Tennessee (24). These states are in the sample because $\mathrm{BHCs}$ have acquired banks there during recent
The sample is restricted to nonmetropolitan counties because BHCs commonly list increased trust services as public benefits when applying to acquire banks in those areas. Furthermore, relatively few banks in nonmetropolitan areas offer trust services, and it is in these areas that BHCs can be expected to have the greatest effect on the total supply of trust services offered if they have any effect at all.

The names and sizes of the BHCs represented in the study are given in Table II. In most counties in which BHCs were represented, only one bank was a subsidiary of a BHC. In one councy in Tennessee

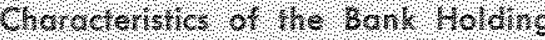
Compenes ho he sample $\mathrm{wr} \mathrm{s} / \mathrm{wr}$

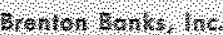
10140,1000001010 .

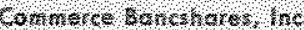

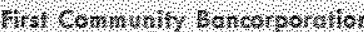

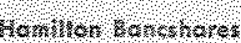

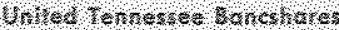

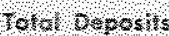
Swestams $0 \mathrm{Son} \mathrm{s} \rightarrow \mathrm{s}$

2010

2337

123

8.80

21,5

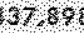

Some countios in Frorida were arignaly included in the emonica analys bu were later excluded becanse those cotnies noreased the standard error of estimate substantialy. rhis result is probably due to a large ramber of retired people in Florida who have a higher rato of monhuman wealth to income than people in the other three stares in the study. vith data for floride included in the sample and dommy wribles added for states ony the dummy variable for Florida counties has a regression conticient that was signillcantly different from zero.

Fitometropolitan countes ate those outside Standard Meropolitar Statistical Areas. 


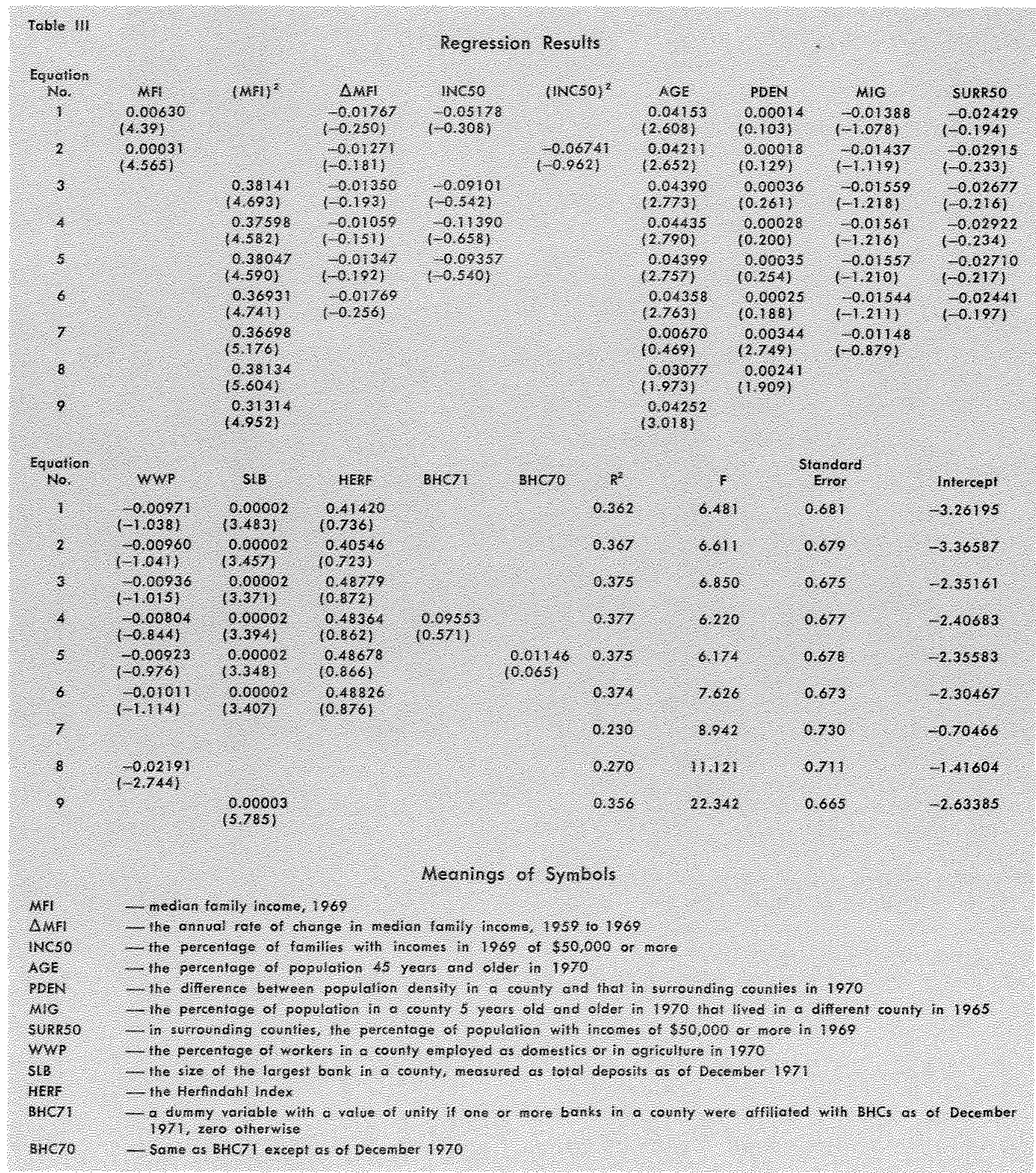

Hamilton Bancshares and United Tennessee Bancshares have each owned a bank. Brenton Banks, Inc. owned three banks in one county and two banks in another county in lowa. The third colmm of Table II gives the number of counties in the study in which each BHC is represented. Total deposits of subsidiary banks in the BHCs as of December 1971 ranged from $\$ 111.13$ million to $\$ 4.4$ billion.

\section{FMPIPTCAL TESULTS}

The influence of the various independent variables on trust revenue per capita is estimated by using 
ordinary least squares regression analysis. The regression results are presented in Table III (p. 13). The $t$-statistics are presented in parentheses below the regression coefficients.

Approximately 37 percent of the variation in trust revenue per capita is explained in equations that include all of the independent variables. There is collinearity among the independent variables, making it difficult to determine the contribution of individual independent variables to explaining trust revenue (see Table IV for an indication of the pairwise collinearity). An equation which includes only the following three variables explains about 35 percent of the variation in the dependent variable: median family income, the percentage of population 45 years and older, and the total deposits of the largest bank in the county.

Several variables were included in the equations in nonlinear form to see if the fit of the equations would be improved. The fit of the equations is better with median family income squared. Squaring the percentage of families with incomes over $\$ 50,000$ does not improve the fit of the equation substantially.

Two variables are highly correlated with the size of the largest bank: (a) the population density in a county less than population density in surrounding counties and (b) the percentage of workers employed as domestics and in agriculture, a proxy for workers without pension plans (see Table IV). The estimated regression coefficients of these variables have the hypothesized signs and are statistically significant in two equations that delete the size of the largest bank in the county as a variable (see Equations 7 and 8), but are not statistically significant when that variable is added to the equation. The results in equations $7-9$ illustrate that with collinearity the t-statistics for regression coefficients vary greatly depending upon which independent variables are included. Under those circumstances it is difficult to say that one variable explains trust revenue and another does not.

Dummy variables that indicate the presence of banks that have been acquired by BHCs have regression coefficients which are not significantly different from zero (see Equations 4 and 5). These results are consistent with either of the following two interpretations: (a) some BHCs have attracted the potential trust customers of their smaller subsidiary banks to be customers of their larger subsidiaries, while other BHCs have helped their smaller subsidiaries attract customers for their own trust departments, and these influences are of equal strength, or (b) BHCs have

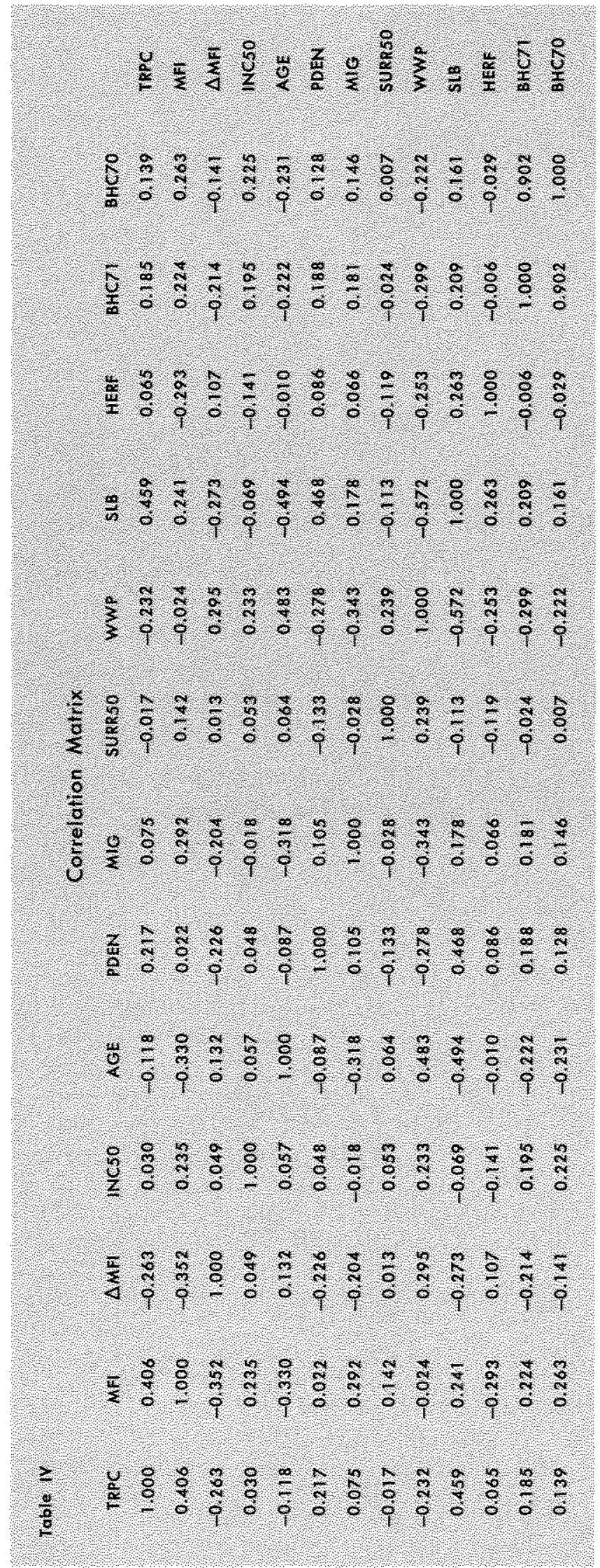


had no influence on the markets for trust services of their smaller bank subsidiaries through either channel. The tests for the statistical significance of the regression coefficients cannot discriminate between these two hypotheses.

Collinearity among the independent variables may be the influence which causes the t-statistics of the regression coefficients for the dummy variables representing $\mathrm{BHC}$ affiliation to be so small as to indicate lack of statistical significance. Given that possibility, a relevant question is: what is the economic signifcance of those dummy variables for trust revenue if the question of statistical significance is ignored? 'The dependent variable is measured as dollars of trust revenue per capita. Therefore, the regression coeffcient of the dummy variable BHC 71 indicates that trust revenue per capita was about $\$ 0.10$ higher on average in areas in which one or more banks were subsidiaries of BHCs, holding other factors constant. The difference was about $\$ 0.01$ using the dummy BHC 70. These differences are so small as to indicate little economic significance, especially since for the sample of counties trust revenue per capita ranges from $\$ 0.005$ to $\$ 4.823$.

Equations 1-3 and 6-9 in Table III were reestimated using average trust revenue per capita in the years 1969-71 as the dependent variable. This was done to determine whether a significant amount of random variation could be removed by averaging over several years. The regression results with this dependent variable are not substantially different from those results in Table III. The predictive ability of the independent variables is not substantially higher with the dependent variable, trust revenue, averaged over three years, indicating little variation in the trust revenue of banks over several years.

\section{SUMMAPI AND CONCLUSTONS}

The purpose of this paper is to estimate the influence of bank holding companies (BHCs) on the trust revenue of banks in areas in which banks are affiliated with BHCs. Remarks in other studies indicate that BHCs could be expected to either increase or decrease the trust activities of their smaller subsidiary banks, depending upon the policies of the BHCs. Empirical results of this paper indicate that the trust revenue of banks in counties in which one or more banks are affliated with $B H C s$ is neither higher nor lower than in other counties, holding other factors constant. This indicates either that BHCs follow different policies concerning the trust business of their smaller banks or that they have had no influence on the trust revenue of banks.

This paper presents equations for estimating the level of trust business of banks in county areas using several variables which are assumed to influence the demand for or supply of trust services. The trust business of banks is measured as the revenue of bank trust departments in each county per person living in the county. The following variables are the most useful for estimating the trust revenue per capita: median family income, the percentage of population 45 years and over, and the size of the largest bank in the area.

The results of this paper have an implication for the regulation of BHCs. The empirical results do not indicate an influence of BHCs on the trust revenues of banks in areas with subsidiaries of BHCs. Therefore, it is appropriate, to give little weight to promises by BHCs that they will increase trust services offered to customers of their subsidiary banks until some evidence is presented to support this contention.

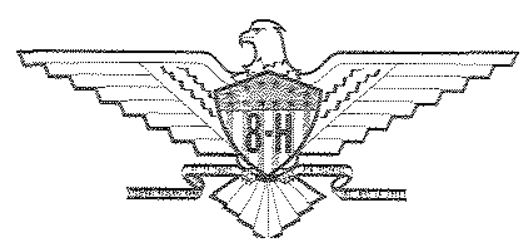

